мотивов, изображают чувства, которые толкают действующих лиц на отчаянные шаги, как на подвиги, так и на преступления, описывают страсти, ставшие причиной неудач или же основанием для зарождения новых отношений. Анализ текстового материала показал, что фреймовые структуры на обозначение эмоций и чувств являются эффективным средством в изображении внутреннего мира литературных героев, а также действенным механизмом экспликации авторской прагматики.

Ключевые слова: фрейм, фреймовая структура, терминал, терминальный элемент, чувство, эмоция.

Kozak Sofiia. Frame "Feeling" in Fictional Discourse (on the material of the literary work of the Austrian writer S. Zweig). The article deals with the analysis of the frame structures denoting feelings in the literary discourse. The notions "frame" and "frame structure" have been viewed from different angles. Frames are qualified as cognitive formations, the component parts of which are the terminals and which are being realized in the discourse by means of the frame structures. The key constituents of the frame structures are the terminal elements which are directly related to the language realization of the terminals. The research has been carried out on the material of Stefan Zweig's novel «Ungeduld des Herzens» («Beware of Pity», literally: «The Heart's Impatience»)). In this literary work the frame structures have been analyzed, in which the terminal elements representing the frame "Feeling" portray personages' emotional sphere and disclose their inner world. In the present research the structure of the frame "Feeling" has been described and its main terminals have been defined. This frame is considered as a mental formation based on the categorial knowledge of human feelings - the fact that people sense not with the mind but inwardly, "in the heart", for instance fear, relief, joy, unconcern, uncertainty etc. On the basis of the dictionary definition the basic terminals of the frame «FEELING» («GEFÜHL») were determined: «Internal Aspiration» («seelische Regung»), «Sensation» («Empfindung»), «Mood» («Einstellung»), «Attitude to the World» («Haltung zur Welt»). Within the framework of the stated terminals the complex analysis of the lexical units denoting feelings of the literary characters of the novel "Ungeduld des Herzens" has been carried out, different nuances of their emotional experience and thoughts have been shown, the innermost dreams have been revealed and the most thinkable aspirations of human soul have been depicted. The analyzed frame structures give a key to understanding of heroes' behavior and their motives, represent their feelings that incite them to reckless acts, both to feats and to evil deeds, portray passions which can become the cause of a failure as well as the basis for the beginning of the new relationships. The analysis of the text material has shown that the frame structures denoting emotions and feelings are an effective means in the representation of the inner world of the literary heroes as well as an efficient mechanism of the explication of the author's pragmatics.

Key words: frame, frame structures, terminal, terminal element, feeling, emotion.

DOI: https://doi.org/10.32782/2410-0927-2020-13-11

УДК $811.111^{\prime} 42:[316.7: 316.658]: 177.1$

Еліна Коляда, Анастасія Шнайдер

\title{
РЕАЛІЗАЦІЯ КОМУНІКАТИВНИХ СТРАТЕГІЙ НЕГАТИВНОЇ ВВІЧЛИВОСТІ В БРИТАНСЬКОМУ Й АМЕРИКАНСЬКОМУ ПОЛІТИЧНОМУ ДИСКУРСІ
}

У статті досліджено особливості реалізації комунікативних стратегій і тактик негативної ввічливості в сучасному британському й американському політичному дискурсі. Негативна ввічливість являє собою детально розроблений набір комунікативних стратегій, спрямованих на демонстрацію визнання незалежності співрозмовника. Негативну ввічливість вважають основою шанобливої поведінки.

Увага до обраної теми зумовлена тим, що ввічливість є невід’ємним елементом мовлення політичних діячів, що сприяє формуванню соціального іміджу політика. Стратегії й тактики негативної ввічливості є ефективними інструментами для регулювання процесів комунікації. Вони сприяють уникненню конфліктів, розвитку та підтримці гармонійних відносин між комунікативними партнерами. Матеріалом дослідження слугували тексти промов експрезидента США Дональда Трампа й колишньої прем'єр-міністра Великої Британії Терези Мей.

Проаналізовано особливості реалізації трьох найбільш уживаних у рамках політичного дискурсу комунікативних стратегій негативної ввічливості: стратегії ухилення, стратегії вибачення та стратегії апелювання до норми. Комунікативні стратегії негативної ввічливості спрямовані на 1) дистанціювання співрозмовників, 2) демонстрацію визнання адресантом незалежності й особистісної автономії адресата, 3) переконання адресата у відсутності наміру в адресанта порушити його особистісні кордони, 4) мінімізацію тиску на адресата з боку адресанта.

Стратегія ухилення реалізується за допомогою тактики обмеження власною оцінкою, тактики перепитування й тактики пом'якшення категоричності висловлення. Стратегія вибачення актуалізується тактикою визнання завданої шкоди та тактикою визнання небажання зашкодити. Стратегію апелювання до норми реалізовує тактика демонстрації загальноприйнятих правил і вимог, що регулюють поведінку членів соціуму. Виявлено, що Тереза Мей надає перевагу офіційно-діловому стилю мовлення, у той час як Дональд Трамп більше тяжіє до неформального стилю мовлення, що зумовлено низкою культурних, соціальних і ситуативних чинників.

Ключові слова: негативна ввічливість, комунікативна стратегія, комунікативна тактика, адресант, адресат, політичний дискурс.

(C) Коляда Е., Шнайдер А., 2020 
Вступ. Актуальність теми дослідження зумовлена загальною спрямованістю сучасної лінгвістичної науки на аналіз різних типів дискурсу й політичного зокрема. Також важливим чинником $є$ необхідність отримання достовірних результатів щодо особливостей мовленнєвої реалізації стратегій і тактик негативної ввічливості в англомовному політичному дискурсі.

Починаючи $з$ 80-х років XX ст., спостерігаємо тенденцію до зростання наукового інтересу до категорії ввічливості з боку багатьох гуманітарних напрямів: психології, етнопсихології, психолінгвістики, соціолінгвістики, прикладної лінгвістики, теорії комунікації, прагматики. Філологічна дискусія, започаткована П. Браун і С. Левінсоном у монографії «Politeness: Some universals in language usage» [2], в умовах сьогодення набуває нового змісту в працях вітчизняних і зарубіжних дослідників (Н. Бабич, В. Литовченко, О. Мельничук, М. Стельмахович, Г. Каспер, Р. Лакофф, Р. Уоттс, Б. Фрейзер та ін.), у яких досліджено зв’язок увічливості із соціальними нормами та стереотипами, окреслено взаємозв'язок увічливості 3 конверсаційними максимами, висвітлено ввічливість в аспекті дотримання конверсаційного контракту [4, с. 104].

Мета дослідження - установити та проаналізувати комунікативні стратегії й тактики негативної ввічливості, якими послуговуються Дональд Трамп і Тереза Мей у своїх політичних промовах. Мета дослідження зумовлює виконання таких завдань: 1) окреслити теоретичне підгрунтя дослідження комунікативних стратегій і тактик негативної ввічливості; 2) виокремити мовні засоби реалізації комунікативних стратегій і тактик негативної ввічливості на прикладах промов Терези Мей та Дональда Трампа; 3) з'ясувати мовленнєві особливості реалізації комунікативних стратегій і тактик негативної ввічливості, які застосовують Тереза Мей та Дональд Трамп;

Методи та методики дослідження. Мета й завдання роботи визначили застосування комплексу загальнонаукових і спеціальних методів дослідження. Серед загальнонаукових використано індукцію, дедукцію, аналіз і синтез, за допомогою яких досліджено та узагальнено теоретичні передумови вивчення реалізації комунікативних стратегій i тактик негативної ввічливості в англомовному політичному дискурсі, а також прагматичний аналіз із метою визначення стратегічно-тактичного потенціалу політиків і зіставний метод - для виявлення спільних і відмінних мовних засобів реалізації стратегій та тактик кожного з обох політиків.

Результати та дискусії. Тенденції дослідження категорії ввічливості визначила праця американських науковців П. Браун та С. Левінсона «Politeness: Some universals in language usage» [2], у якій проаналізовано теоретичне підгрунтя ввічливості як культурного та лінгвістичного феномену. Відповідно до цієї теорії, стратегії негативної ввічливості спрямовані на демонстрацію поваги до співрозмовника, визнання його особистісних кордонів та незалежності, а також підкреслення того, що жоден із мовців не має наміру порушувати особистісні кордони партнера чи якимось чином загрожувати його автономії [2, c. 95]. Головним поняттям концепції П. Браун і С. Левінсона $є$ «обличчя» (the public self-image), що вперше запропоноване Е. Гофманом, як певне уявлення щодо конкретної особи в соціумі, іiі репутація в очах інших, своєрідна позитивна цінність, яку мовці прагнуть зберегти в процесі комунікації [3, с. 21]. Щоб гарантувати ефективне міжособистісне спілкування, мовці повинні намагатися зберегти не лише власне «обличчя», а й також «обличчя» співрозмовника. Задля досягнення цієї мети мовці використовують відповідні комунікативні стратегії, які, зі свого боку, реалізуються з допомогою комунікативних тактик.

У нашому дослідженні опиратимемося на визначення стратегії й тактики Ф. Бацевича, який стверджує, що «комунікативна стратегія - це оптимальна реалізація інтенцій мовця щодо досягнення конкретної мети спілкування, тобто контроль і вибір дієвих ходів спілкування та гнучкої їх видозміни в конкретній ситуації» [1, с. 121], а «комунікативна тактика - це визначена лінія поведінки на певному етапі комунікативної взаємодії, спрямована на одержання бажаного чи запобігання ефекту небажаного; мовленнєві прийоми, які дають змогу досягнути комунікативної мети і виконують функцію способів здійснення стратегії мовлення» [1, с. 122].

П. Браун та С. Левінсон [2] виокремлюють «негативне обличчя» (Negative Face) i «позитивне обличчя» (Positive Face). Перше розуміють як бажання людини мати свободу дій, бути незалежною, неприпустимість утручання з боку інших; «позитивне обличчя» - бажання 
бути залученим до взаємодії з іншими. Ці «обличчя» співвідносяться 3 такими стратегіями ввічливості, як стратегія позитивної ввічливості (positive politeness) - мовець визнає право слухача на повагу до його «обличчя» та стверджує дружність і взаємність їхніх відносин; стратегія негативної ввічливості (negative politeness) - мовець визнає цінність «обличчя» співрозмовника, але при цьому враховує, що на це «обличчя» здійснюється певний вплив, який загрожує свободі його волевиявлення; такий вид взаємодії зумовлює застосування таких стратегій, котрі сприяють зменшенню подібної втрати свободи [2, с. 69 - 70].

Основою шанобливої поведінки (heart of respective behaviour) П. Браун і С. Левінсон називають саме негативну ввічливість. Вона являє собою детально розроблений набір комунікативних стратегій, спрямованих на демонстрацію визнання незалежності співрозмовника. Зазначені характеристики комунікативних стратегій негативної ввічливості зумовлюють широке їх уживання саме в рамках політичного дискурсу. Т. Ширяєва [7], яка відносить політичний дискурс до інституційного різновиду спілкування, підкреслює, що інституційному дискурсу властиві шаблонність та передбачуваність, які принципово відрізняють його від персонального [7, с. 21]. До основних характеристик інституційного дискурсу дослідниця зараховує статусно-рольову обумовленість, спеціалізований характер, клішованість i регламентованість, що відображає етнічні цінності соціуму загалом та цінності окремої суспільної групи, що становить інститут [7, с. 46].

Розглянемо особливості вживання основних комунікативних стратегій негативної ввічливості в політичному дискурсі на прикладі промов експрезидента США Дональда Трампа та колишньої прем'єр-міністра Великої Британії Терези Мей.

Комунікативна стратегія ухилення. На думку I. Місягіної [6], ухильність як комунікативна стратегія реалізується задля збереження репутації співрозмовника, підтримання його комунікативного статусу (щоб уникнути його критики, не образити його, поставитись із розумінням та терплячістю до його слів тощо). На позначення явища ухильності англомовними науковцями переважно використовується термін «геджинг», що означає намагання мовця ухилитися від повідомлення інформації за допомогою вживання обережних, непрямих, невизначених та двозначних висловлень, які дають можливість уникнути відповідальності за твердження та залишити шлях для відступу. У деяких випадках, коли йдеться про непряме недемонстративне ухиляння від надання інформації, що реалізоване вербально, «ухильність» $\mathrm{i}$ «геджинг» можна вважати взаємозамінними [6, с. 119-120].

Стратегія ухилення втілена в промовах Терези Мей і Дональда Трампа за допомогою тактик обмеження власною оцінкою, перепитування, пом'якшення категоричності висловлення.

Тактика обмеження власною оцінкою полягає в наданні мовцем суб'єктивних міркувань щодо розуміння якості, характеру, значення, змісту певної дії. Одним із найпоширеніших мовленнєвих засобів, що реалізує зазначену тактику, виступає гедж well, особливо часто така тактика трапляється в промовах Терези Мей. Наприклад: attack [10];

1) Well, we've had another terrorist attack in London on the London Underground. Cowardly

2) Well, it is necessary for us to look, as we are doing, at whether our police and security services have the full capabilities, the powers that they need [10].

Вищенаведені висловлення взяті з інтерв’ю Терези Мей після терористичного акту в Лондонському метро у 2017 p. Спілкуючись із журналістами, вона намагається бути максимально делікатною у висловленнях й уникати категоричності. Цим політик демонструє, що наявна інформація не є остаточною.

Дональд Трамп, послуговуючись цією тактикою, удається до комбінації Well + I believe:

3) Well, I believe if you think that you can't have it, you probably won't have it. You have to go into everything with a positive attitude [8].

Ще однією тактикою стратегії ухилення, яку використовують Тереза Мей і Дональд Трамп, є тактика перепитування. За допомогою цієї тактики мовець прагне продемонструвати свою неупередженість і заручитися підтримкою співрозмовника. При цьому мовним засобом виступає граматична структура, у якій дієслівний питальний конституент don't you agree? або don't you think?, приєднаний до розповідного речення. Наприклад: 
4) So now we're actually getting the testing. It's likely there are a lot more people out there who are going to come and actually be sick, don't you think? [11].

Стратегія ухилення також актуалізується за допомогою тактики пом'якшення категоричності висловлення. Найпоширенішим засобом, до якого вдається в цьому плані Дональд Трамп, є властиві розмовному мовленню геджі sort of та тауbe. Наприклад:

5) So it is sort of curious. A man works for us, with us very closely, Dr. Fauci, and Dr. Birx also, highly thought of [13].

Тереза Мей частіше, утім, використовує геджі probably i perhaps.

6) And another issue I'm going to be talking about is something that most people probably don't think about, don't think happens [11].

Використання вищезазначених геджів зумовлено потребою мовця підкреслити вірогідність своєї думки й знизити ступінь ії категоричності.

Комунікативна стратегія вибачення. Застосовуючи комунікативну стратегію вибачення, мовець визнає завдані ним незручності й засвідчує те, що шкодує про це [2, с. 186]. Як підкреслює О. Малая [5], суть стратегії вибачення полягає в намірі співрозмовників донести певну думку: «Я не хочу обмежувати твоєї свободи, тому відчуваю свою провину за те, що якимось чином обмежив іiі» [5, с. 159]. Комунікативними тактиками реалізації стратегії вибачення є тактика визнання завданої шкоди та тактика визнання небажання зашкодити.

Тактику визнання завданої шкоди комунікативної стратегії вибачення репрезентують такі лексичні одиниці та вилови: be sorry, excuse me, pardon, forgive me, apologise. Зазначені засоби реалізації прямого вибачення допомагають мовцеві чітко й водночас щиро показати співрозмовнику психологічний дискомфорт, який він переживає через завдану шкоду. Ці та синонімічні до них вислови є доволі частовживаними в промовах Дональда Трампа та Терези Мей. Наприклад:

7) Theresa May: And I want to apologise to you today. Because we are genuinely sorry for any anxiety that has been caused [14].

У цьому прикладі Тереза Мей використовує конструкцію be genuinely sorry, щоб особливо підкреслити співчуття своєї команди й власні 3 приводу завданих незручностей. Загалом, Тереза Мей значно частіше застосовує подібні звороти, у той час, як Дональд Трамп обмежується коротшими й лаконічнішими формулами вибачення:

8) I apologize to my family. I apologize to the American people. Certainly I'm not proud of it [11].

Можливо, саме за таку свою небагатослівність низка англомовних видань назвала його «президентом, котрий ніколи не вибачається». Адже навіть у своєму відеозверненні 2016 р., де він вибачався за публічні образи на адресу жінок, він теж обмежився доволі стриманим коментарем і більше апелював до почуттів своєї аудиторії та пояснень власних мотивів, аніж концентрувався на безпосередніх вибаченнях:

9) Anyone who knows me knows these words don't reflect who I am. I said it, I was wrong, and I apologise [11].

Наступною тактикою, яку можна помітити в промовах Дональда Трампа й Терези Мей, $\epsilon$ тактика визнання небажання зашкодити слухачеві, яка є протилежною попередній, адже мовець прагне попередити слухача про майбутнє нанесення шкоди його обличчю. Цю тактику можна проілюструвати таким прикладом, у якому Тереза Мей попереджає, що їй доведеться зайняти ще трохи часу у своїх колег. Наприклад:

10) I hope the House will forgive me if I take a moment to remind it of those changes [12].

Комунікативна стратегія вибачення слугує засобом відновлення гармонії в стосунках, націленим на повагу до особистості комунікативного партнера. Висловлення вибачення повідомляє співрозмовнику, що мовець шанує його, демонструє жаль, який відчуває з приводу вчиненої ним негативної дії, що загрожувала обличчю комунікативного партнера.

Комунікативна стратегія апелювання до норми. Комунікативна стратегія апелювання до норми полягає в намірі мовця зняти із себе відповідальність за виконання акту, котрий загрожує «обличчю» адресата, посилаючись на усталені суспільні та етичні норми [2, с. 85]. Найпоширенішою в цьому випадку є тактика демонстрації загальновизнаних правил і вимог, що регулюють поведінку членів соціуму, характер їхніх відносин, взаємодії й спілкування. 
Поширеним граматичним засобом реалізації стратегії апелювання до норми в політичному дискурсі є безособові речення типу It is important/vital/right/ necessary та модальні дієслова should, must. Наприклад:

11) Well, it is necessary for us to look, as we are doing, at whether our police and security services have the full capabilities, the powers that they need [10];

12) And it is important to recognise this fact. June the 23rd was not the moment Britain chose to step back from the world [14].

У наведених прикладах Тереза Мей уживає конструкції It is necessary/ important, щоб наголосити на важливості сказаних нею слів для кожного громадянина, адже в згаданих промовах вона коментує терористичний акт у Лондоні та початок процедури Брекзиту. Послуговуючись стратегією негативної ввічливості, Тереза Мей апелює до значущості вищевказаних подій і намагається цим привернути до них увагу громадськості.

Розглянемо ще приклад:

13) While we must remain vigilant, it is clear that our aggressive strategy is working, and very strongly working I might add [8].

У наведеному прикладі з прес-конференції щодо пандемії коронавірусу Дональд Трамп уживає комунікативну стратегію апелювання до норми задля демонстрації загальновизнаних правил і вимог, що регулюють поведінку членів соціуму. Він використовує модальне дієслово must, щоб підкреслити важливість сказаного й донести думку про те, що саме правила й наявні суспільні норми обмежують свободу адресата.

Висновки. У своїх промовах Тереза Мей і Дональд Трамп послуговуються трьома комунікативними стратегіями негативної ввічливості: стратегією ухилення, стратегією вибачення й стратегією апелювання до норми. Стратегія ухилення реалізується 3 допомогою тактики обмеження власною оцінкою (гедж well, конструкція well + I believe), тактики перепитування (питальні конституенти don't you agree? або don't you think?), тактики пом'якшення категоричності висловлення (геджі sort of, maybe, probably, perhaps). Стратегія вибачення актуалізується тактикою визнання завданої шкоди й тактикою визнання небажання зашкодити (вислови be sorry, excuse me, forgive me). Стратегію апелювання до норми реалізовує тактика демонстрації загальноприйнятих правил і вимог, що регулюють поведінку членів соціуму (конструкції It is important/ vital/ right/ necessary, модальні дієслова should, must). Виявлено, що Тереза Мей надає перевагу офіційно-діловому стилю мовлення, у той час як Дональд Трамп більше тяжіє до неформального, що зумовлено низкою культурних, соціальних та ситуативних чинників.

\section{References}

1. Batsevych, Florii. 2004. Osnovy komunikatyvnoi linhvistyky. Kyiv.

2. Brown, Penelope and Stephen C. Levinson. 1987. Politeness: Some universals in language usage. Cambridge: Cambridge University Press.

3. Goffman, Erving. 1967. Interaction Ritual: Essays on Face to Face Behavior. Harmondsworth: Penguin.

4. Lutsenko, Liudmyla. 2016. "Stratehii pozytyvnoi vvichlyvosti v dyskursyvnii praktytsi bryfinhu. Filolohichni studii”. Naukovyi visnyk Kryvorizkoho derzhavnoho pedahohichnoho universytetu 102-109.

5. Malaia, Olesia. 2008. "Realizatsiia movlennievykh stratehii vvichlyvosti u dyskursi nimetskomovnykh internetforumiv". PhD diss., Kharkiv.

6. Misiahina, Iryna. 2014. "Spivvidnoshennia ukhylnosti ta sumizhnykh poniat". Naukovi zapysky [Vinnytskoho derzhavnoho pedahohichnoho universytetu imeni Mykhaila Kotsiubynskoho]. Seriia : Filolohiia (movoznavstvo) 20: $118-122$.

7. Shyryayeva, Tetyana. 2008. "Kognitivnoe modelirovanie institucionalnogo delovogo diskursa". PhD diss., Krasnodar.

8. Donald Trump. Coronavirus Press Conference Transcript, July 21st, 2020. URL: https://www.rev.com/blog/ transcripts/donald-trump-coronavirus-press-conference-transcript-july-21

9. Rona Barrett's interview of Donald Trump, 1980. URL: https://www.washingtonpost.com/ rona-barrett-1980interview-of-donald-trump.pdf

10. PM statement following medal attack in Manchester: May 23rd, 2017. URL: https://www.gov.uk/government/ speeches/pm-statement-23-may-2017

11. Transcript of Donald Trump's Videotaped Apology, 2016. URL: https://www.nytimes.com/2016/10/08/ us/donald-trump-apology-statement.html 
12. George Stephanopoulos interviews British Prime Minister Theresa May, May 2018. URL: https://abcnews.go.com/ ThisWeek/full-transcript-british-prime-minister

13. Donald Trump Press Conference Transcript on Coronavirus Testing, May 10th, 2020. URL: https://www.rev.com/ press-conference-on-coronavirus-testing-may-10

14. Statement made by the Prime Minister, November 15th, 2018. URL: https://www.gov.uk/government/ speeches/statement- 15-november-2018

Коляда Элина, Шнайдер Анастасия. Реализация коммуникативных стратегий негативной вежливости в британском и американском политическом дискурсе. В статье исследуются особенности реализации коммуникативных стратегий и тактик негативной вежливости в современном британском и американском политическом дискурсе. Материалом исследования послужили тексты речей экс-президента США Дональда Трампа и бывшего премьер-министра Великобритании Терезы Мэй. Охарактеризованы речевые особенности реализации коммуникативных стратегий и тактик негативной вежливости, которые применяют в своей речи Тереза Мэй и Дональд Трамп. Внимание к избранной теме обусловлено тем, что вежливость является неотъемлемым элементом речи политических деятелей, содействующим формированию определенного социального имиджа политика. Стратегии и тактики негативной вежливости являются эффективными инструментами для регулирования процессов коммуникации. Они способствуют избежанию конфликтов, развитию и поддержанию гармоничных отношений между коммуникативными партнерами.

Анализируются особенности реализации трех наиболее употребляемых в рамках политического дискурса коммуникативных стратегий негативной вежливости: стратегии уклонения, стратегии извинения и стратегии апеллирования к норме. Коммуникативные стратегии негативной вежливости направлены на 1) дистанцирование собеседников, 2) демонстрацию признания адресантом независимости и личностной автономии адресата, 3) убеждение адресата в отсутствии умысла адресанта нарушить его личностные границы и 4) минимизацию давления на адресата.

Стратегия уклонения реализуется при помощи тактики ограничения собственной оценкой, тактики переспрашивания, тактики смягчения категоричности высказывания. Стратегия извинения актуализируется тактикой признания ущерба и тактикой признания нежелания навредить. Стратегию апеллирования к норме реализует тактика демонстрации общепринятых правил и требований, регулирующих поведение членов социума. Обнаружилось, что Тереза Мэй предпочитает официально-деловой стиль речи, в то время как Дональд Трамп больше тяготеет к неформальному, что обусловлено рядом культурных, социальных и ситуативных факторов.

Ключевые слова: негативная вежливость, коммуникативная стратегия, коммуникативная тактика, адресант, адресат, политический дискурс.

Koliada Elina, Shnaider Anastasiia. Implementation of Communicative Strategies of Negative Politeness in British and American Political Discourse. The article deals with the peculiarities of the implementation of communicative strategies and tactics of negative politeness in British and American political discourse. The material for the study was the written texts of speeches of former US President Donald Trump and former British Prime Minister Theresa May. The chosen topic is of great interest due to the fact that politeness is an integral part of political speeches, contributing to the formation of a politician's social image.

The main concept in linguistic politeness is face which represents a person's public self-image. There are two distinct types of face: a positive face and negative face, which then lead to the division of negative and positive politeness strategies. Negative politeness means respect and it can be seen as formal politeness. Negative politeness strategies address the addressee's negative face by showing distance and impersonality. The linguistic means and speech features of the implementation of communicative strategies and tactics of negative politeness, used by Theresa May and Donald Trump, have been identified. Negative politeness strategies and tactics are effective tools for regulating communication processes. They add to the development and maintenance of harmonious relationships between communicative partners.

The features of the implementation of the three most commonly used negative politeness strategies have been analyzed: the strategy of evasion, the strategy of apology, and the strategy of the invocation of established norms. Negative politeness strategies convey respect and deference to the addressee and are aimed at 1) distancing the interlocutors, 2) demonstrating the addresser's recognition of the addressee's independence and personal autonomy, 3) convincing the addressee that the addresser does not intend to violate his/her personal boundaries, and 4) minimizing pressure on the addressee.

The strategy of evasion is implemented by the tactic of restraining by personal opinions, the tactic of questioning, and the tactic of mitigation, the strategy of apology - by the tactic of admitting harm and the tactic of admitting unwillingness to harm, the strategy of the invocation of established norms - by the tactic of demonstrating generally accepted rules and requirements that govern the behaviour of members of society.

Key words: negative politeness, communicative strategy, communicative tactic, addresser, addressee, political discourse. 